解 説

\title{
モンテカルロ・シミュレーションを用いた定量的危険度分析
}

\author{
杉浦勝明

\section{Quantitative Risk Analysis Using Monte Carlo Simulation}

\author{
Katsuaki SUGIURA
}

\section{はじめに}

定量的危険度分析は, 世界貿易機関 (WTO) の衛生検 疫協定 (SPS 協定) の下, 自国の衛生検疫措置を正当化 するための手段の 1 つとしてその適用が加盟国に求めら れているだけでなく, 実際の家畜衛生・公衆衛生のリス ク管理の道具として注目され, 欧米, オセアニア諸国で 応用されつつある $4,5,6) 。$

筆者が勤務する国際獣疫事務局 (OIE) でも, SPS 協 定に基づく家畜衛生分野の国際基準の設定機関として, 輸入危険度分析のガイドラインの開発に世界の専門家の 協力を得て取り組んでいる3,6)。

筆者は，これまで，この分野の何人かの専門家との情 報交換, いくつかの文献を通じ, モンテカルロ・シミュ レーションを用いた定量的危険度分析の手法を修得する 機会を得たところ, 取りまとめて紹介する。まず, 家畜 衛生の危険度分析のモデリングでよく用いられる確率分 布, モデルの構築方法について説明し, 最後にモンテカ ルロ・シミュレーションを用いた定量的危険度分析の具 体例を紹介する。

\section{1. モンテカルロ・シミュレーションとは？}

家畜衛生の定量的危険度分析にあたっては，モデルの 各変数として最も蓋然性が高い推定值 (最期待值) を入 力して結果を出し，その上で入力変数をいろいろと変え て感度分析を行いどのように結果が変わるかをみるとい う方法がよくとられてきた8),99。

たとえば，ある農場から動物を導入した場合にある疾

連絡先: Office International des Epizooties (OIE), Scientific and Technical Department (国際獣疫事務局科学技術部) 12, rue de Prony, 75017, Paris, France

Tel : 33-1-441151888, Fax : 33-1-42670987

k.sugiura@oie.int
表 1 ある母集団から導入する 1 頭の動物が感染して いる確率を求めるための危険度分析モデルの例

\begin{tabular}{|c|c|c|c|}
\hline & 最小值 & 最期待値 & 最大值 \\
\hline 母集団の有病率 ( $\mathrm{p}$ ) & 0.3 & 0.4 & 0.5 \\
\hline 臨床検査の感度 $(q)$ & 0.01 & 0.1 & 0.2 \\
\hline 精密検査の感度 ( $r$ ) & 0.8 & 0.9 & 0.95 \\
\hline
\end{tabular}

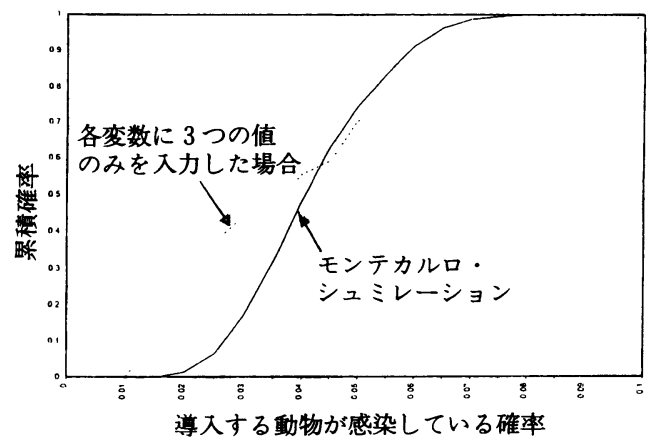

図1 モンテカルロ・シミュレーションと各変数に 最小值, 最期待値及び最大值の 3 つの值のみ を入力した場合との比較

病 Xが侵入する危険度を分析するための単純なモデル を考之てみる。動物は, 農場の母集団から無作為に抽出 され, 臨床検査と精密検查を受けた後出荷されるとする。 このモデルでは, 農場における疾病 $\mathrm{X}$ の有病率 $\mathrm{p}$, 出荷 前に実施される臨床検查の感度 $(\mathrm{q})$ と精密検查の感度 $(\mathrm{r})$ が入力変数として使われる。疾病Xが導入先の農場に侵 入するのは, 抽出された動物が感染し, かつ, 臨床検查 と精密検查で見逃される場合であり，これらの事象はす べて独立して生じることから, 侵入の確率は $\mathrm{p} *(1-\mathrm{q})$ * $(1-\mathrm{r})$ で計算される。各変数として入力する確率とし て, データ不足などによる不確実性を反映し, 最低值, 最期待値及び最大值の 3 つの值を使うことができる（表 1)。

この場合, 3 つの変数それぞれに 3 つの值の可能性が 
あるので, 全部で $3 \wedge 3=27$ 通りもの組合せが存在する 上, 各変数として最低值と最大值の間のいかなる值でも

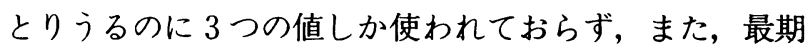
待值が最低值と最大值と同一のウェイトで使われている との問題がある。

モンテカルロ・シミュレーションを用いた定量的危険 度分析も多数のシナリオを発生される点では上述の方法 によく似ているが, 各変数の値として最低值と最大值の 間の可能性のある多数の值がとられ，可能性のあるシナ リオがその発生する確率に応じてウェイトが置かれるこ とから, 各変数の不確実性を合理的に反映させた実際的 な結果が得られるとの優れた点がある(図 1)。定量的危 険度分析では，不確実な変数には確率分布が用いられる。

モンテカルロ・シミュレーションは, 変数に入力した 確率分布から種々の値をその確率密度又は量に応じ抽出 し, 繰り返し計算を行うものであり，手計算では膨大な 時間がかかることから、コンピュー夕を用いて行われる。

\section{2. 家畜衛生の危険度分析で用いられる確率分布}

家畜衛生の危険度分析において変数として入力する確 率の值については, データが不十分な場合, 限られたデ 一夕から確率分布の形で推定しなければならない。また， 将来の事象を予測する場合には, 事象の生じる仕組みが 完全にわかっていても（データが完全にそろっていて も), 変動の発生を避けられない場合がある。このように 確率分布は変数の不確実性又は変動を示すのに用いられ る。家畜衛生の危険度分析でよく使われる確率分布は, 二項式プロセスに基づく確率分布，ポアソン・プロセス に基づく確率分布, 超幾何分布, 正規分布である。ここ では，後述の実例で登場する，二項分布，べー夕分布， 三角分布及びパート分布について説明する。

\section{（1）二項分布}

二項分布及び次のベー 夕分布は, 二項式プロセス に基づく確率分布である。 二項式プロセスは,一定の 試行回数 $(\mathrm{n}) ， そ の$ 試行の 成功率 $(\mathrm{p})$ 及び成功数 (s) の 3 つのパラメータから なる。二項式プロセスは， すべての試行が独立して いること(各試行の成功率 は前回の試行が成功する か失敗するかを問わず前 回の成功率と同じこと）を前提としている（たとえば, 大きな母集団から一定の頭数を抽出検査して摘発される

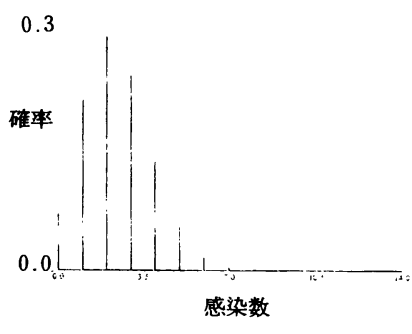

図 312 頭中に含まれる感染頭数の分布 (Binomial $(12,0.2))$
感染畜の頭数)。試行回 数 $(\mathrm{n})$, その試行の成 功率 $(\mathrm{p})$ 及び成功数 ( $\mathrm{s}$ ) のうちの 2 つが判明し ていれば, 残りの $1 つ$ の值を確率分布の形で 推定することができる (図2)。

ある事象の成功率が 施るとき， $\mathrm{n}$ 回の試行における成功数(その じる回数）は，二項分布を示す。すなわち， 成功数 $(\mathrm{s})=\operatorname{Binomial}(\mathrm{n}, \mathrm{p})$

二項分布の確率量関数 $\mathrm{f}(\mathrm{x})=\left(\begin{array}{c}\mathrm{n} \\ \mathrm{x}\end{array}\right) \mathrm{P}^{\mathrm{x}}(1-\mathrm{p})^{\mathrm{n}-\mathrm{x}}$ から, $\mathrm{n}$ 回の試行で 1 回も成功しない確率は, $\mathrm{f}(0)=(1-\mathrm{p}) \hat{\text { n }}$ で あり，したがって，少なくとも 1 回成功する確率は， $\mathrm{f}(>$ $0)=1-(1-\mathrm{p})$ 个nである。

例 1 ：有病率0.2の大きな母集団から12頭を無作為に抽出した場合 の12頭中に含まれる感染頭数の分布は, $\operatorname{Binomial}(12,0.2)$ である （図 3 ）。また, 感染動物が少なくとも 1 頭含まれる確率は, $1-(1-$ 0.2 ^12=0.931である。

(2) ベータ分布

$\mathrm{n}$ 回の試行においてある事象が $\mathrm{r}$ 回観察された場合, その事象が生じる確率は, ベー夕分布を示す。すなわち, 確率 $(\mathrm{p})=\operatorname{Beta}(\mathrm{r}+1, \mathrm{n}-\mathrm{r}+1)$ ベー夕分布の平均值は, $(\mathrm{r}+$

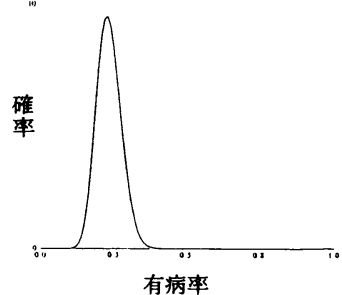

有病率

凶4 原肉の有病军の分布 $(\operatorname{Beta}(24,78))$

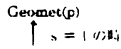

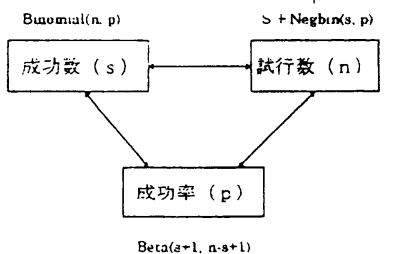

成功数 $(\mathrm{s})$, 試行数 $(\mathrm{n})$, 成功本 $(\mathrm{p})$ の 方2つのパラメーターがかかれば、 項分布は $\mathrm{s}=1$ の時, 幾何分布を示す

図 2 二項式プロセス (図 4 )。 1) / $(\mathrm{n}+2)$ であり, 分散は, $(\mathrm{r}+$ 1) $*(\mathrm{n}-\mathrm{r}+1) /(\mathrm{n}+2)^{\wedge} 2 *$ $(\mathrm{n}+3)$ であることから, $\mathrm{r} / \mathrm{n}=$ $\mathrm{p}$ とすると， $\mathrm{n}$ の值を大きくす ると, 平均値及び標準偏差は, $\mathrm{p}$ 及び $\sqrt{\mathrm{p} *(1-\mathrm{p}) / \mathrm{n}}$ にれ ぞれ近似する。これは，抽出検 査の結果から母集団の有病率の 分布を推定する際に用いる算式に相当する。

例 2 ：大きな豚群から 100 頭を無作為に抽出して検查したところ, 23頭がオーエスキー病に感染していることが判明した。この豚群の 有病率は, $\operatorname{Beta}(23+1,100-23+1)=\operatorname{Beta}(24,78)$ と推定される

（3）三角分布及びパート分布

これらの分布は，実際のデータがなく，専門家の意見 などを基にして推定する場合等に用いられる。すなわち， $\mathrm{a}=$ 最小值, $\mathrm{b}=$ 最期待值， $\mathrm{c}=$ 最大值とした時，確率

$(\mathrm{p})=\operatorname{Triang}(\mathrm{a}, \mathrm{b}, \mathrm{c})$ 又は $\operatorname{Pert}(\mathrm{a}, \mathrm{b}, \mathrm{c})$

三角分布の平均值は, $(\mathrm{a}+\mathrm{b}+\mathrm{c}) / 3$ であり, パート分布 の平均值は, $(\mathrm{a}+4 \mathrm{~b}+\mathrm{c}) / 6$ である。これらの平均值の算 式が示すように，三角分布は，最大值と最小值を過大評 
価する欠点がある。 0.3

パート分布では, 平均値の算出にあ たって最期待值に 4 倍の比重が置か れている。最低値 と最大值の比重を

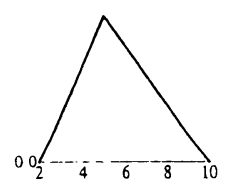

0.3 .

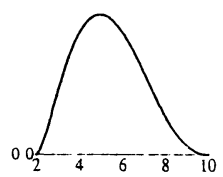

困5年間輪入量の分布 (Triang $(2,5,10)$ と Pert $(2,5,10))$
さらに減らすために最期待値に 7 倍の比重を置いた分布 もある10)。

例 3 : 食肉の輸入危険度分析において,解禁後の年間㡏入量を推定 する必要がある時, 仮に専門家の意見等を踏まえて, 予想される輸 入量を年間 2 万トンから 10 万トン（最期待值 5 万トン）と推定した 場合, 年間輸入量の分布は, Triang $(2,5,10)$ 又は $\operatorname{Pert}(2,5,10)$ と仮定することができる（図 5 )。

\section{3. 危険度分析モデルの輠築}

定量的危険度分析モデルの構築は, まずモデルの構造 を決定し, 次に，モデルにおける変数を定量化し，各変 数間の相互関係をモデルに組み入れなければならない。

（1）モンテカルロ・シミュレーションができる表計算ソ フトの種類

モンテカルロ・シミュレーションを行うことができる ソフトウェアの環境がいくつかある7。最も一般的なの は，表計算ソフトに米国 Palisade 社の@RISK 又は Decisioneering 社の Crystal Ball をアッド・インして表 計算ソフトの機能を拡張したものである。後述の実例は， Microsoft Excelに@RISKをアッド・インして行った ものである。

\section{（2）表計算モデルの設計}

モンテカルロ・シミュレーションを用いた定量的危険 度分析モデルは, 問題に対する解答をもたらすように設 計しなければならないのは，言うまでもないが，変数に 単一の値を入力して行う危険度分析と異なり，特に，次 の点に注意する必要がある10)。すなわち,

(1) モデルに使われる算式は，不確実な変数の可能性の あるすべての值について可能性のあるすべての組合せが 確保されるように構築しなければならない。

(2) モデルのダイナミックな性質からして，一般に，問 題をいくつかの要素に分解しなければならない。そうす ることにより, 変数間の関係を考慮したり, 不確実な各 変数を正確にモデル化することが可能となる。

(3) 各変数に入力する確率分布は, 変動 (variability) 又 は不確実性 (uncertainty) を表している。これらは区別 してシミュレートする必要がある。これらを組み合わせ ることは, 数学的に, 正しくなく, また, 問題のリスク を過大評価する原因となる。

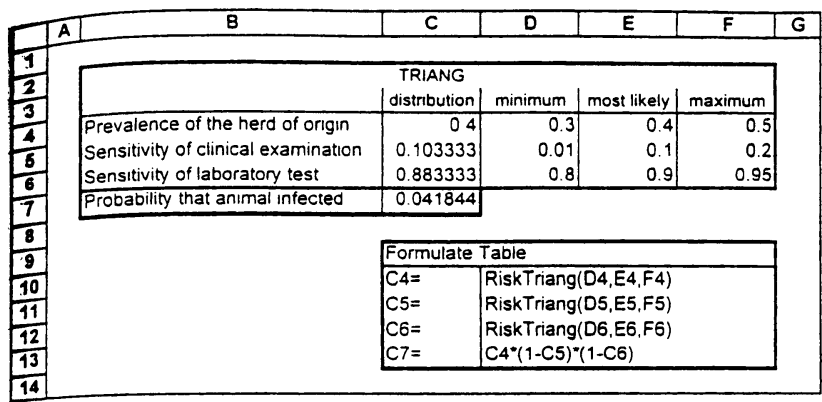

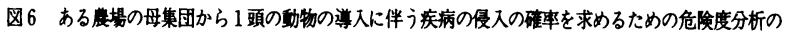
表計算モデルの設計例（表1及块 1 に奶応）

（3） ある農場から動物を導入した場合にある疾病 X が 侵入する危険度を分析するという冒頭の例で使ったモデ ルを図6に示した。このモデルは, @RISK ソフトをアッ ドインしてモンテカルロ・シミュレーションを可能にし た表計算ソフト危険度 Microsoft Exel を用いて設計し た。@RISKにより追加された関数は, RiskTriangのよ うに Risk の頭文字で始まる1)。このモデルでは，農場の 母集団からの抽出, 臨床検查, 精密検査という動物の感

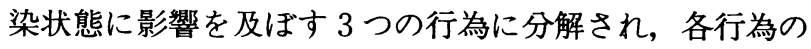
結果生じる事象の確率(有病率 $\mathrm{p}$, 臨床検査の感度 $\mathrm{q}$, 精 密検査の感度 r)に三角分布を用い, これらの事象はすべ て独立して生じることから, 算式 $\mathrm{P}=\mathrm{p} *(1-\mathrm{q}) *(1-$ r）を用いて，侵大の確率 $\mathrm{P}$ を計算した。モンテカルロ・ シミュレーションにより各変数の值を確率分布に応じて 抽出し1000回繰り返し計算した結果得られたのが，図 1 の累積確率曲線である。

\section{4. 定量的危険度分析具体例 1}

ある農場から動物を導入した場合に疾病Xが侵入する 確率を求めるという冒頭の単純な例を少し複雑にし, 次 のような実際にあり得る例を考える。

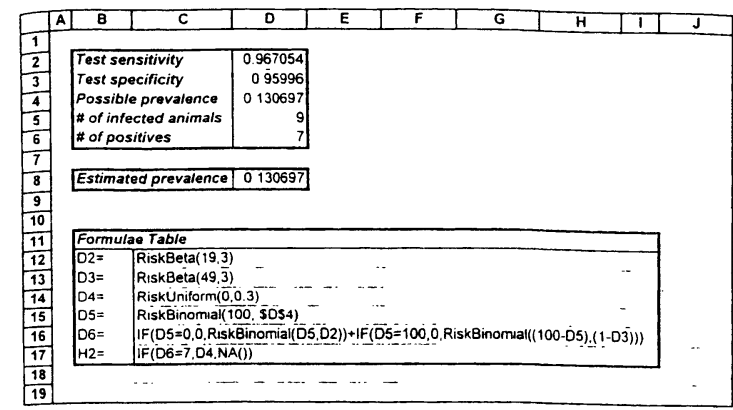

図 7 具体例 1 の表計算モデル 1 


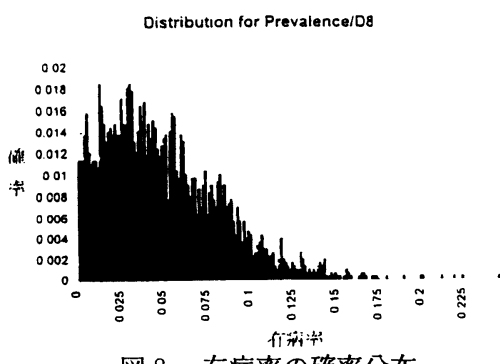

図 8 有病率の確率分布

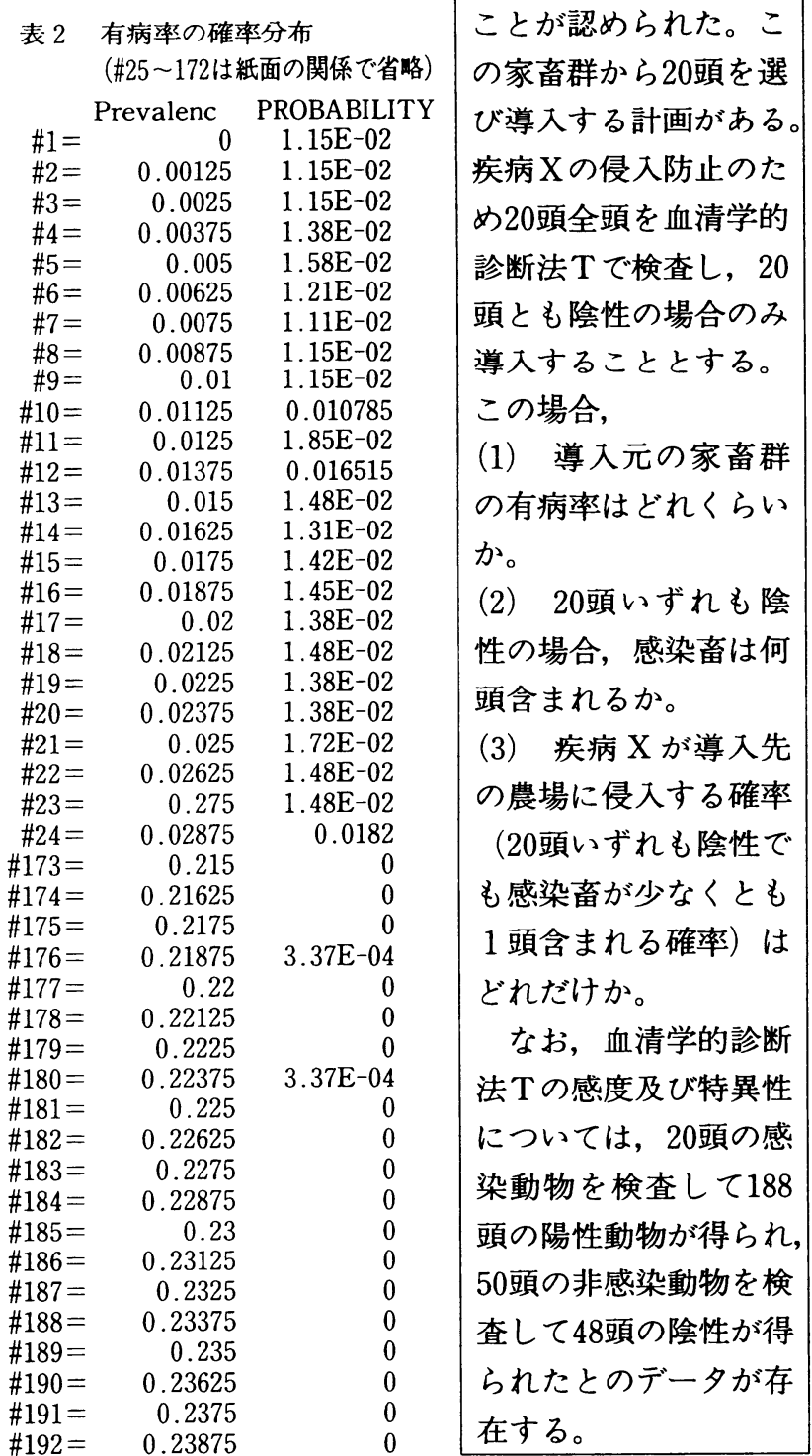

（1）有病率の確定(図 7 及び図 8 )

このような条件下で 有病率を求める方法と して，2つの方法があ る。数学的に求める方 法とシミュレーション

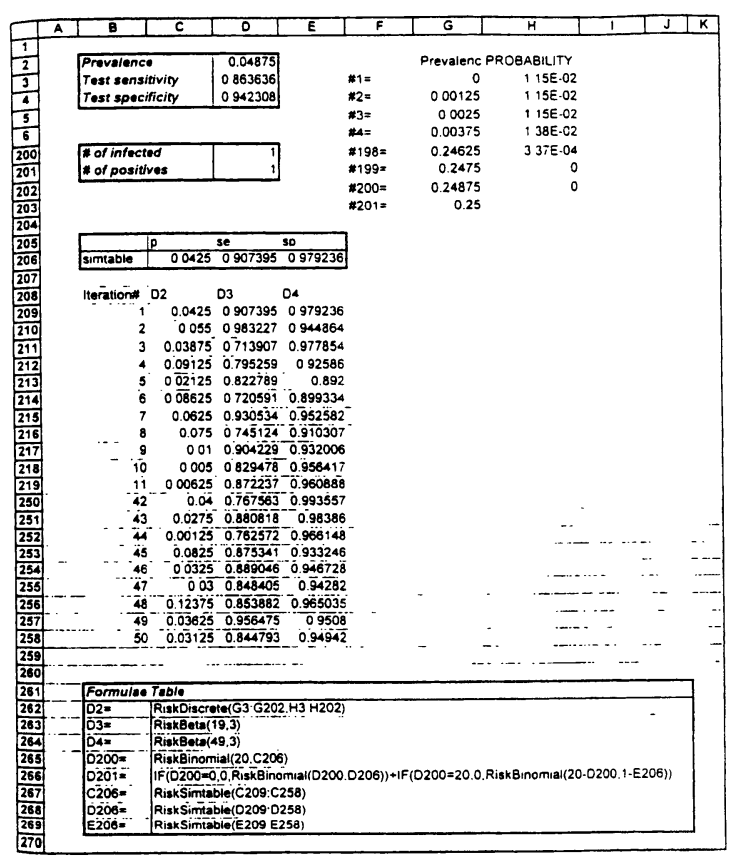

困 9 具体例 1 の表計算モデル 2 （行7 199は紙面の関係で省略）

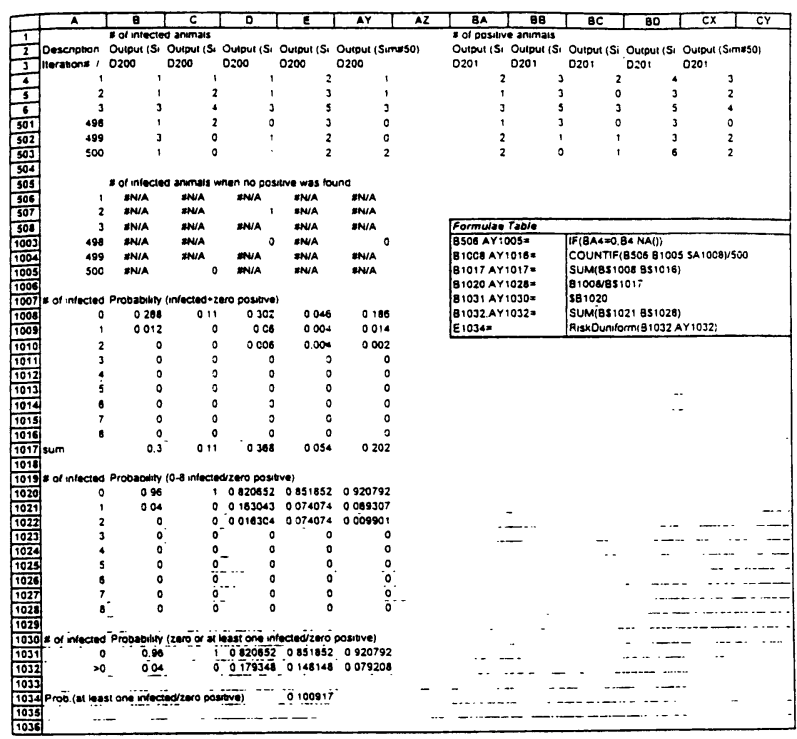

図10 具体例 1 の表計算モデル 3（行7 500, 行509 1002, 列D AX及び 列 $\mathrm{BE} \sim \mathrm{CW}$ は紙面の関係で省略)

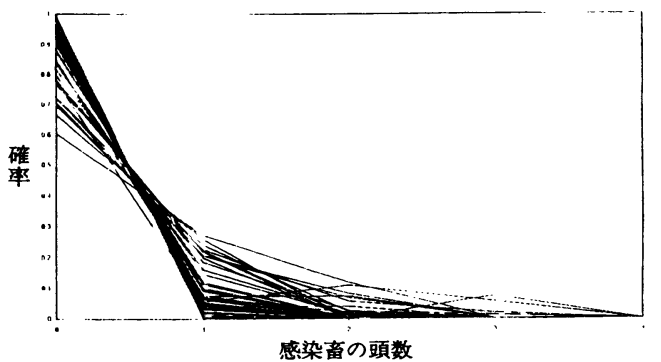

図11陽性畜が認められなかった場合の感染畜の頭数の分布 Page.1 
により求める方法である。ここでは, シミュレーション により求めた。

まず, 血清学的検查法 $\mathrm{T}$ の感度 $(\mathrm{Se})$ 及び特異性 $(\mathrm{Sp})$ は, 次式により推定される。

$$
\text { 感度 }(\mathrm{Se})=\operatorname{RiskBeta}(18+1,20-18+1)
$$$$
=\operatorname{RiskBeta}(19,3)(\text { 図 } 7 \text { セル D2) }
$$

特異性 $(\mathrm{Sp})=\operatorname{RiskBeta}(48+1,50-48+1)$

$$
=\operatorname{RiskBeta}(49,3) \text { (図 } 7 \text { セル D3) }
$$

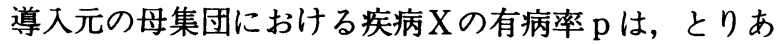
えず，0から0.3のいかなる值も可能性があるとして，

$\mathrm{x}=$ RiskUniform $(0,0.3$ ) (図 7 セル D4)

とする。(これは，指定された 2 つの值のいずれも同じ確 率で出現するという連続分布である。）と，このような母 集団から無作為に選んだ100頭に含まれる感染畜の頭数 は,

感染畜の頭数 $(\mathrm{d})=\operatorname{Risk} \operatorname{Binomial}(100, \mathrm{x})$ (図 7 セル D5) さらに陽性畜の頭数は陽性畜の頭数 (c) =真の陽性 頭数十偽の陽性頭数

$=\operatorname{RiskBinomial}(\mathrm{d}$, Se $)+\operatorname{RiskBinomial}(100-\mathrm{d}$, $1-\mathrm{Sp}$ ) (図 7 セル D6)

となる。ここで, 100頭検査した結果， 7 頭の陽性畜が得 られたことがわかっていることから，IF 関数を用いて， 陽性畜の頭数(c)が 7 のときのみ, $\mathrm{x}$ が採用されるような モデルを作った。(図 7 セル D8)。D8を出力変数に指定し このモデルをラテン・ハイパーキューブ抽出法で 100,000 回繰り返し計算したところ, 図 8 及び表 2 の最低值 0 , 最大値 0.249 , 平均值 0.0496 , 標準偏差 0.0352 の確率分布 が得られた。

（2） 20 頭とも陰性の場合にその20頭に含まれる感染畜 の頭数の推定（図 9）表 2 の有病率の確率分布のデー夕 を新しいワークシートに移し替える（図 9 のセル G3： H202)。このデータをシミュレーションに使うため, Ris$\mathrm{kDiscrete}(\{\mathrm{x} 1, \ldots \mathrm{xn}\},\{\mathrm{p} 1, \ldots, \mathrm{pn}\})$ を用いる。これ は, 一連のパラメータの値が指定した確率で出現すると いう不連続分布である。このよjにして，3つの変数の 分布が次のとおり推定される。

有病率 $=$ RiskDiscrete (F3：F202, G3：G202）（図 9 のセル D2)

検查法の感度 $=\operatorname{RiskBeta}(19,3)$ （図 9 のセル D3）

検査法の特異性 $=\operatorname{RiskBeta}(49 ， 3) （$ 図 9 のセル D4）

さて, 次に, これらの 3 つの変数の值を用いて, 抽出 した20頭がいずれも陰性であった場合に含まれる感染畜 の頭数を求める。

感染畜の頭数は有病率を成功率とする二項分布をとる。 同様に, 真の陽性頭数は感度を成功率, 偽の陽性頭数は 特異性の補数を成功率とする二項分布をとることから，
上述の 3 つの変数の確率分布を

感染畜の頭数 $(d)=\operatorname{RiskBinomial}(20, p)$

陽性畜の頭数 $(\mathrm{c})=\operatorname{RiskBinomial}(\mathrm{d}, \mathrm{Se})$

+ RiskBinomial $(100-\mathrm{d}, 1-\mathrm{Sp})$

に入力し, IF 関数により $\mathrm{c}=0$ の場合に $\mathrm{d}$ の值が採用さ れるようにし，シミュレーションを行うことにより，感 染畜の頭数を求めるという方法が思いつくが, この方法 では，不確実性と変動が分離されないとの問題が生じる。 そこで，筆者は不確実性と変動を分離するため次のよう なセカンド・オーダー・モデリングを試みた。

まず，有病率，感度及び特異性の 3 つの不確実性を反 映した確率分布を有する変数についてラテン・ハイパー キューブ法により無作為に50回の抽出を行う。抽出され たそれぞれ50個の值をワークシートに移す（図 9 のセル C209：E258)。これらの50組の值を前述の感染畜及び陽 性畜の頭数を求める関数に入力し, 感染畜の頭数（セル D200）及び陽性畜の頭数（セル D201）を出力変数に指定 し, 各組について 500 回ずつ繰り返し計算するというシミ ュレーションを行う。50の各組の值が順番にシミュレー ションに用いられるよう各変数の50個の值を関数 RiskSimtableでくくった（セルC206，D206及び E206）。

このシミュレーションにより得られたデー夕をさらに 別のワークシートに移し替之（感染畜の頭数：図10セル B4：AY503及び陽性畜の頭数：セル BA4：CX503), 陽 性畜の頭数が 0 の場合の感染畜の頭数を求める（セル B506：AY1005)。セル B1008：セル AY1016は，陽性畜 の頭数が 0 でかつ感染畜の頭数が $\mathrm{i}$ 頭であるケースの出 現の確率であるので，これを陽性畜が 0 頭である確率で 割ることにより，陽性畜が 0 頭の場合に感染畜が $\mathrm{i}$ 頭ま れる条件付確率を求める（セル B1020：AY1028）。これ をグラフ化したのが図11である。このグラフの50本の各 折線間の差は入力変数の不確実性を反映している。すな わち，有病率，感度及び特異性に関する情報が十分でな いことから，陽性畜の頭数が 0 頭である場合に感染畜が 含まれない確率は $61 \%$ から $100 \%$ と幅広い分布をとるこ とがわかる。同様に，感染畜が 1 頭含まれる確率は $0 \%$ ～30\%の分布をとり，2 頭含まれる確率は $0 \%$ ～15\%， 3 頭含まれる確率は $0 \sim 8 \% ， 4$ 頭含まれる確率は $0 \%$ であることがわかる。

（3） 20 頭いずれも陰性の場合に感染畜が少なくとも 1 頭含まれる確率の推定 図10のセル B1032：AY1032は, 20頭いずれも除性の場合に感染畜が少なくとも 1 頭含ま れる確率の分布である。これをグラフ化するため, RiskDiscrete でこれらの值をくくり, シミュレーションを 行った。結果は, 図12のとおりであり，0\%から39\%と 幅広い分布を示している。 
（4）シミュレーションの結果の解釈 図11及び図12か ら20頭いずれも陰性の場合に感染畜が含まれない確率は 61 100\%とかなり幅があることがわかり, さらに図12か らは信頼度 $95 \%$ を確保するためには感染畜が含まれる確 率が最大 $30 \%$ もり，導入もとの母集団の有病状況に对 し適用したリスク管理措置は十分でないことがわかる。 この結果を踏ま之, 家畜衛生措置の決定者（この場合, 導入先の農場主）は，十分なりスク管理のためには，結 果の不確実性の原因である入力変数の不確実性を低減す るため有病率等に関するデー夕を充実させた上で, 危険 度の評価を再度試みるか, それが不可能な場合には, 導 入をあきらめるか，又は，導入に当たっての検疫措置を 追加する等の判断を行うことができる。

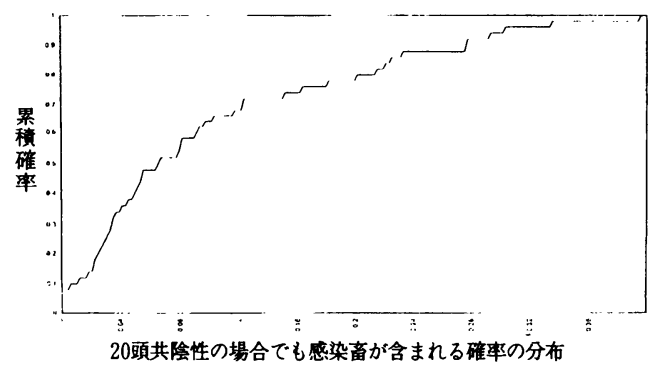

図12 陽性畜が認められなかった場合に感染畜が含まれる確率の分布

\section{5. 定量的危険度分析の具体例 2}

次に畜産物の定量的危険度分析の例を挙げる。

$\mathrm{A}$ 国には恐ろしい豚の疾病 $Z$ の不顕性感染が存在する $\mathrm{A}$ 国の母集団から無作為に抽出した1000頭の豚を検査し たところ，17頭が疾病 $Z$ に感染していた。これらの17頭 をと殺したところ，17頭のうち 6 頭の枝肉が疾病 $Z$ の病 原体に污染されていた。これら 6 頭分の枝肉を骨抜き， 冷凍したところ，半分から疾病 $Z$ の病原体が検出された。 さて，B国の獣医当局は，A国からの一本当たり $7 \sim 9$ $\mathrm{kg}$ の骨なし冷凍もも豚肉 5 トンの輸入許可要請に対し, 許可を行うか否かを判断するため，仮に許可した場合の

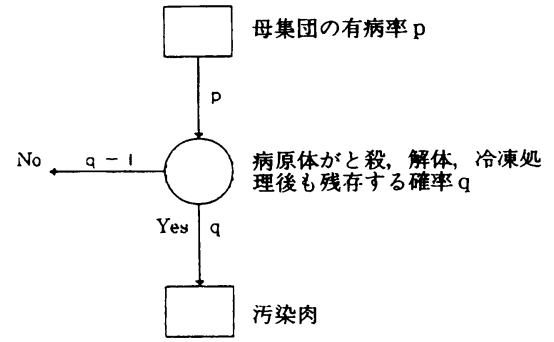

図13 具体例 2 のイベント・ツリー （豚肉が輸出されるまで）
危険度分析 を行うこと とした。次 の確率を順 次求めよ。 (1) A 国 から仮に骨 なし冷凍豚 肉を 1 頭分 輸入した場
合に疾病 Zの病原体に污染されている確率

（2）A国から仮に骨なし冷凍豚もも肉 5 トンを輸入し た場合に疾病 $Z$ の病原体に污染されたもも肉が少なくと も 1 本輸入される確率

さらに，B国の獣医当局は，A国からの骨なし冷凍豚 肉の解禁（部位，量を限定しない解禁）の要請に対し， 解禁を行うか否かを判断するため，仮に解禁した場合の 危険度分析を行うこととした。次の確率を順次求めよ。

（3）Ａ国から仮に骨なし冷凍豚肉の輸入を全面解禁し た場合に疾病 $Z$ の病原体に污染された骨なし冷凍豚肉が 1 年間に少なくとも 1 頭分輸入される確率

(4) A国から仮に骨なし冷凍豚肉の輸入を全面解禁し た場合，同輸入が原因で疾病 $Z$ が $\mathrm{B}$ 国で年間少なくとも 1 件発生する確率

なお，(3) 及び(4)の確率の計算に当たっては，解禁後 の輸入量などを推定する必要があるが，これらのデー夕 については, その推定方法とともに，確率の計算時に示 すこととする。

（1）A国から仮に骨なし冷凍豚肉を 1 頭分輸入した場 合に疾病 $Z$ の病原体に污染されている確率 $\mathrm{P}$

$$
\begin{gathered}
\text { 図13のイベント・ツリーより, } \\
\mathrm{P}=\mathrm{p} * \mathrm{q} \quad \cdots \text { (1) }
\end{gathered}
$$

ここで, $\mathrm{p}$ は豚が農場からの出荷時に感染している確率

で，検査結果より次の分布をとる（図14のセル G5）。

$$
\mathrm{p}=\operatorname{beta}(17+1,1000-17+1)=\operatorname{beta}(18,984)
$$

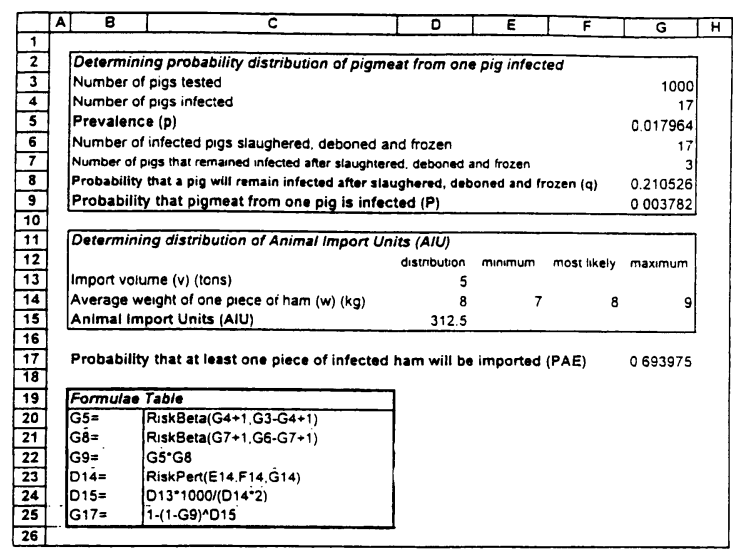

図14 具体例 2 の表計算モデル 1

q は, 感染豚から生産された骨抜き冷凍豚肉に疾病 $Z$ の 病原体が残存している確率で，感染豚のと殺，骨抜き及 び凍結の結果より次の分布の分布をとる（図14のセル G8)。 $\mathrm{q}=\operatorname{beta}(3+1,17-3+1)=\operatorname{beta}(4,15) こ れ ら の$ 分布を式!に代入し（図14のセル G9)，P を出力変数に指 定し, モンテカルロ・シミュレーションを行うと, 平均 值0.0038, 標準偏差0.0019のの確率分布が得られる（表 
表 3 具体例 2 の表計算モデル 1 のシミ 表 4 具体例 2 の表計算モデル 2 のシミ ユレーションの結果

@RISK Simulation of Risk Analysis-product 1.xls Simulations $=1$

Iterations $=5000$

\begin{tabular}{|c|l|l|}
\hline Name & $\begin{array}{l}\text { Probability } \\
\text { that pigmeat } \\
\text { from one pig } \\
\text { is infected }\end{array}$ & $\begin{array}{c}\text { Probability } \\
\text { that infected } \\
\text { pigmeat } \\
\text { imporoed }\end{array}$ \\
\hline Description & Output & Output \\
\hline
\end{tabular}

\begin{tabular}{|l|l|l|}
\hline Cell & G9 & G17 \\
\hline
\end{tabular}

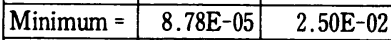

\begin{tabular}{l|r|r|} 
Maximum $=$ & 0.0152409 & 0.9929661 \\
\hline
\end{tabular}

\begin{tabular}{|l|r|r|}
\hline Mean $=$ & $3.79 \mathrm{E}-03$ & 0.6454276 \\
\hline Ste Deviation $=$ & $1.92 \mathrm{E}-03$ & 0.1757545 \\
\hline Variance $=$ & $3.67 \mathrm{E}-06$ & $3.09 \mathrm{E}-02$ \\
\hline
\end{tabular}

\begin{tabular}{|r|r|r|}
\hline Variance $=$ & $3.67 \mathrm{E}-06$ & $3.09 \mathrm{E}-02$ \\
\hline Skewness & 1.009704 & -0.4136949 \\
\hline
\end{tabular}

\begin{tabular}{|r|r|r|}
\hline Skewness $=$ & 1.009704 & -0.4136949 \\
\hline Kuntosis $=$ & 4.48885 & 2.589666 \\
\hline
\end{tabular}

\begin{tabular}{|l|r|r|}
\hline Kurtosis $=$ & 4.488845 & 2.589666 \\
\hline Mode $=$ & $2.62 \mathrm{E}-03$ & 0.5457782 \\
\hline $5 \%$
\end{tabular}

\begin{tabular}{|c|c|c|}
\hline $5 \%$ Perc $=$ & $1.29 \mathrm{E}-03$ & 0.3296672 \\
\hline $10 \%$ Perc $=$ & $1.66 \mathrm{E}-03$ & 0.4024363 \\
\hline
\end{tabular}

\begin{tabular}{|c|c|c|}
\hline $10 \%$ Perc $=$ & $1.66 \mathrm{E}-03$ & 0.4024363 \\
\hline
\end{tabular}

\begin{tabular}{|l|l|l|}
\hline $15 \%$ Perc $=$ & $1.91 \mathrm{E}-03$ & 0.4507811 \\
\hline $20 \%$ Perc & $2.15 \mathrm{E}-03$ & 0.4894898 \\
\hline
\end{tabular}

\begin{tabular}{l|l|l|}
\hline $20 \%$ Perc $=$ & $2.15 \mathrm{E}-03$ & 0.4894898 \\
\hline
\end{tabular}

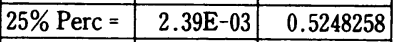

\begin{tabular}{|r|r|r}
\hline $30 \%$ Perc $=$ & $2.60 \mathrm{E}-03$ & 0.556545 \\
\hline
\end{tabular}

\begin{tabular}{|r|r|r|}
\hline $35 \%$ Perc $=$ & $2.79 \mathrm{E}-03$ & 0.5834653 \\
\hline
\end{tabular}

\begin{tabular}{|c|c|c|}
\hline $40 \%$ Perc $=$ & $3.01 \mathrm{E}-03$ & 0.6106306 \\
\hline
\end{tabular}

\begin{tabular}{|r|r|r}
\hline $45 \%$ Perc $=$ & $3.23 \mathrm{E}-03$ & 0.6359587 \\
\hline $50 \%$ Perc & $3.45 \mathrm{E}-0$. & 0.6610597 \\
\hline
\end{tabular}

\begin{tabular}{l|r|r|}
\hline $50 \%$ Perc $=$ & $3.45 \mathrm{E}-03$ & 0.6610597 \\
\hline
\end{tabular}

\begin{tabular}{|l|l|l|}
\hline $55 \%$ Perc $=$ & $3.70 \mathrm{E}-03$ & 0.6869299 \\
\hline $60 \%$ Perc $=$ & $3.98 \mathrm{E}-03$ & 0.7131788 \\
\hline
\end{tabular}

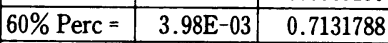

\begin{tabular}{|r|r|r|}
\hline $65 \%$ Perc $=$ & $4.22 \mathrm{E}-03$ & 0.7355126 \\
\hline $70 \%$ Perc $=$ & $4.51 \mathrm{E}-03$ & 0.7586796 \\
\hline
\end{tabular}

\begin{tabular}{l|r|r}
$70 \%$ Perc $=$ & $4.51 \mathrm{E}-03$ & 0.7586796 \\
\hline
\end{tabular}

\begin{tabular}{|c|c|c|}
\hline $75 \%$ Perc $=$ & $4.81 \mathrm{E}-03$ & 0.7819672 \\
\hline $80 \%$ Perc & $5.24 \mathrm{E}-03$ & 0.8069636 \\
\hline
\end{tabular}

\begin{tabular}{r|r|r|}
\hline $80 \%$ Perc $=$ & $5.24 \mathrm{E}-03$ & 0.8069636 \\
\hline $85 \%$ Perc & $5.72 \mathrm{E}-03$ & 0.834258 \\
\hline
\end{tabular}

\begin{tabular}{|r|r|r|}
\hline $85 \%$ Perc $=$ & $5.72 \mathrm{E}-03$ & 0.834258 \\
\hline $90 \%$ Pec & $6.38 \mathrm{E}$ & 0.864697 \\
\hline
\end{tabular}

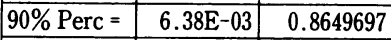

\begin{tabular}{|l|l|l|}
\hline $95 \%$ Perc $=$ & 0.0074621 & 0.9049479 \\
\hline
\end{tabular}

$$
\text { ユレーションの結果 }
$$

QRISK Simulation of Risk Analysis-product 0.xls Simulations $=1$

Iterations $=5000$

\begin{tabular}{|l|l|l|}
\hline \multicolumn{1}{|c|}{ Name } & $\begin{array}{c}\text { Probability } \\
\text { that infected } \\
\text { pigmeat } \\
\text { imported }\end{array}$ & $\begin{array}{l}\text { Probability } \\
\text { of infection } \\
\text { introduced }\end{array}$ \\
\hline Description & Output & Output \\
\hline Cell & G23 & S33 \\
\hline
\end{tabular}

\section{\begin{tabular}{|l|l|l|}
\hline Minimum $=$ & 0.2815786 & $1.01 \mathrm{E}-04$ \\
\hline
\end{tabular}}

\begin{tabular}{|l|r|r|}
\hline Maximum $=$ & 1 & $4.46 \mathrm{E}-02$ \\
\hline Mean $=$ & 0.9902762 & $4.67 \mathrm{E}-03$ \\
\hline
\end{tabular}

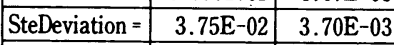

\begin{tabular}{|l|l|l|}
\hline Variance $=$ & $1.41 \mathrm{E}-03$ & $1.37 \mathrm{E}-05$ \\
\hline
\end{tabular}

\begin{tabular}{|c|c|c|}
\hline Skewness = & -7562705 & 2400211 \\
\hline
\end{tabular}

\begin{tabular}{|l|l|l|}
\hline Kurtosis $=$ & 80.7308 & 13.24826 \\
\hline
\end{tabular}

\begin{tabular}{|l|l|l|}
\hline Mode $=$ & 1 & $2.77 \mathrm{E}-03$ \\
\hline $5 \%$
\end{tabular}

\begin{tabular}{|l|l|l|}
\hline $5 \%$ Perc $=$ & 0.9487703 & $9.94 \mathrm{E}-04$ \\
\hline $10 \%$ Perc & 0.981998 & $1.38 \mathrm{E}-03$ \\
\hline
\end{tabular}

\begin{tabular}{l|l|l|}
\hline $10 \%$ Perc $=$ & 0.981998 & $1.38 \mathrm{E}-03$ \\
\hline
\end{tabular}

\begin{tabular}{|l|l|l|}
\hline $15 \%$ Perc $=$ & 0.9912661 & $1.69 \mathrm{E}-03$ \\
\hline
\end{tabular}

\begin{tabular}{|l|l|l|}
\hline $20 \%$ Perc $=$ & 0.9953933 & $1.95 \mathrm{E}-03$ \\
\hline
\end{tabular}

\begin{tabular}{|c|c|}
\hline $25 \%$ Perc $=$ & 0.9976165 \\
\hline
\end{tabular}

\begin{tabular}{|l|l|l|}
\hline $30 \%$ Perc $=$ & 0.9987853 & $2.47 \mathrm{E}-03$ \\
\hline $35 \%$ Perc $=$ & 0.9993842 & $2.47 \mathrm{E}-03$ \\
\hline
\end{tabular}

\begin{tabular}{|l|l|l|}
\hline $35 \%$ Perc $=$ & 0.9993842 & $2.47 \mathrm{E}-03$ \\
\hline
\end{tabular}

\begin{tabular}{|l|l|l|}
\hline $40 \%$ Perc $=$ & 0.9997312 & $3.03 \mathrm{E}-03$ \\
\hline
\end{tabular}

\begin{tabular}{|l|l|l|}
\hline $45 \%$ Perc $=$ & 0.9998729 & $3.36 \mathrm{E}-03$ \\
\hline
\end{tabular}

\begin{tabular}{|l|l|l|}
\hline $50 \%$ Perc $=$ & 0.9999443 & $3.68 \mathrm{E}-03$ \\
\hline
\end{tabular}

\begin{tabular}{|l|l|l|}
\hline $55 \%$ Perc $=$ & 0.9999738 & $4.05 \mathrm{E}-03$ \\
\hline $60 \%$ Perc $=$ & 0.9999889 & $4.49 \mathrm{E}-03$ \\
\hline
\end{tabular}

\begin{tabular}{|l|l|l|}
\hline $60 \%$ Perc $=$ & 0.9999889 & $4.49 \mathrm{E}-03$ \\
\hline
\end{tabular}

\begin{tabular}{|l|l|l|}
\hline $65 \%$ Perc $=$ & 0.9999961 & $4.90 \mathrm{E}-03$ \\
\hline
\end{tabular}

\begin{tabular}{|l|l|l|}
\hline $70 \%$ Perc $=$ & 0.9999989 & $5.39 \mathrm{E}-03$ \\
\hline
\end{tabular}

\begin{tabular}{|l|l|l|}
\hline $75 \%$ Perc $=$ & 0.9999997 & $5.96 \mathrm{E}-03$ \\
\hline
\end{tabular}

\begin{tabular}{|l|l|l|}
\hline $80 \%$ Perc $=$ & 0.9999999 & $6.69 \mathrm{E}-03$ \\
\hline $85 \%$ Perc $=$ & & $7.58 \mathrm{E}-03$ \\
\hline
\end{tabular}

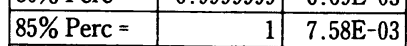

\begin{tabular}{|l|l|l|}
\hline $90 \%$ Perc $=$ & 1 & $9.12 \mathrm{E}-03$ \\
\hline
\end{tabular}

\begin{tabular}{|l|l|l|}
\hline $95 \%$ Perc $=$ & 1 & $9.12 \mathrm{E}-03$ \\
\hline
\end{tabular}
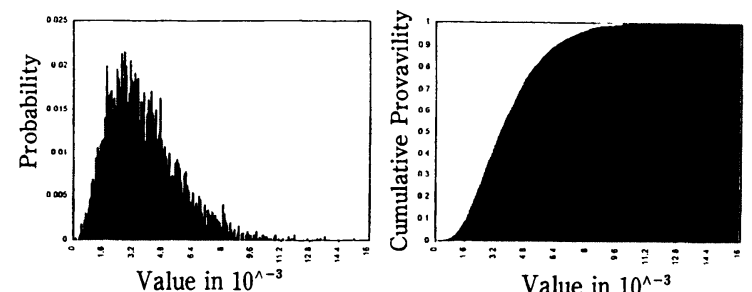

Value in $10^{\wedge-3}$

図15骨なし冷凍豚肉 1 頭分が污染されている確率の分布
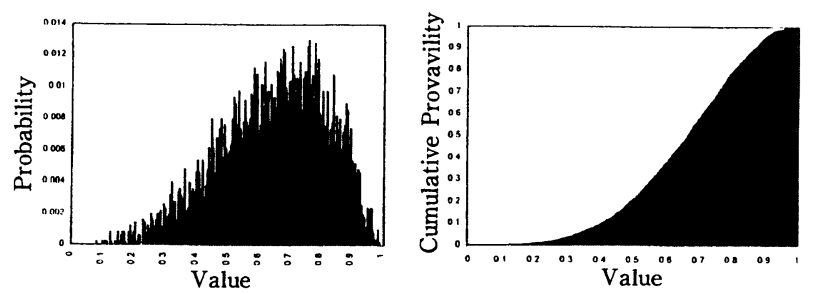

四16骨なし冷凍腞もも肉 5 トン分のうち少なくとも1頭分が污染されている 確率の分布

3 及び図15-1)。図15-2 は同じ分布の累積確率分布で あり, 確率 $95 \%$ で污染の危険度は 0.0075 以下であること がわかる。

（2）A国から仮に一本当たり 7 ～ $9 \mathrm{~kg}$ の骨なし冷凍 豚もも肉 5 トンを輸入した場合に疾病 $Z$ の病原体に污染 されたもも肉が少なくとも 1 本輸入される確率疾病 $Z$ の 病原体が残存する骨なし冷凍豚肉が少なくとも 1 頭分輸

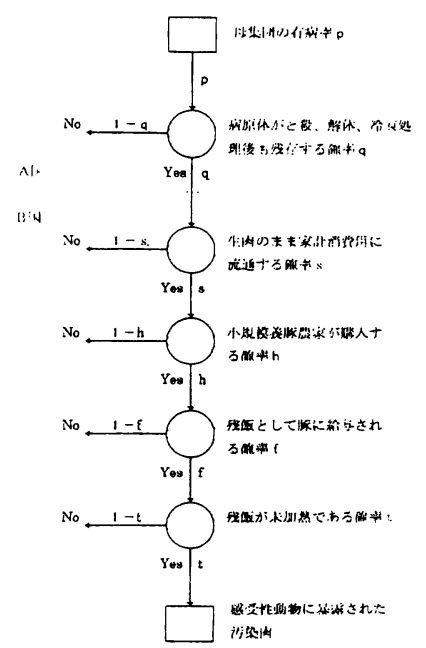

冈17 具体例 2 のイベント・ツリー

(污染原肉か感受牪物に暴露されるまで)
入される確率は, 次の 式により計算される。 $\mathrm{PAE}=1-(1-\mathrm{P})^{\wedge}$ AIU …(2)

ここで, AIUは, 輸 入される骨なし冾凍豚 肉が何頭分に相当する かを表す年間動物輸入 単位数である。AIUは 次により計算される。 $\mathrm{AIU}=$ 骨なし冷凍豚肉 の輸入量 $\mathrm{v} /$ 豚 1 頭分 の豚肉量 $\mathrm{w} \cdots$ (3) 一本当たり $7 \sim 9$ $\mathrm{kg}$ の骨なし冷凍豚も も肉 5 トンが輸入され るとの前提条件より,

分子は $5000 \mathrm{~kg}$ であり, 分母は, 1 頭分のもも肉の重量= $7 \sim 9 \mathrm{~kg} /$ 本 $\times 2$ 本 $=14 \sim 18 \mathrm{~kg}$ である。ここでは,もも 肉 1 本の重量は, 最小値 $7 \mathrm{~kg}$, 最期待値 $8 \mathrm{~kg}$, 最大值 9 $\mathrm{kg}$ のパート分布をとるとした(図14のセル D15)。これら の値を式(3)に代入して AIU 分布を求め（図14のセル D15)，(1)で求めた P の分布とともに式(2)代入し(図14 のセル G17), これを出力変数に指定してシミュレーショ ンを行うことにより, PAEの確率分布が得られる（表 3 , 図16-1 及び図16-2)。これは, 平均値 0.65 , 標準 偏差 0.18 確率分布であり, 污染された骨なし冷凍豚肉 が輸入される危険度は高いことがわかる。

（3）Ａ国から仮に骨なし冷凍豚肉の輸入を全面解禁し た場合に疾病 $Z$ の病原体に污染された骨なし冷凍豚肉が 1 年間に少なくとも 1 頭分輸入される確率

(2)の場合と同様, この確率を求めるためには, AIU を 推定する必要があるが, AIU を求めるために必要なデー 夕（解禁後の $\mathrm{A}$ 国からの年間豚肉輸入量, 豚 1 頭分の豚 肉量）は存在しない。

このため，A国からの骨なし冷凍豚肉の年間輸入量に ついては，専門家の意見を聴いて分布を求める方法 ${ }^{10}$ を 使って推定することとする。3人の専門家に，仮にA国 から骨なし冷凍豚肉の輸入を解禁した場合の年間輸入量 


\begin{tabular}{|c|c|c|c|}
\hline & 最 小値 & 最期待値 & 最 大 值 \\
\hline 専門家 $\mathrm{A}$ & 30 トン & 50 トン & 100 トン \\
\hline 専門家 $\mathrm{B}$ & 20 トン & 80 トン & 150 トン \\
\hline 専門家 $\mathrm{C}$ & 10 トン & 40 トン & 80 トン \\
\hline
\end{tabular}

を推定してもらったところ, 次のとおりであった。

これらの専門家による推定值は，デー夕がない場合の ラフな推定であることから，パート分布をとるものとし た ${ }^{10)}$ 。すなわち，専門家 Aによる推定值 $=\operatorname{pert}(30,50$, 100）（図17のセル C13）, 専門家 $\mathrm{B}$ による推定値 $=$ pert $(20,80,150)$ (図17のセル C14), 専門家 Cによる推定値= pert $(10 ， 40 ， 80)$ (図17のセル C15)

最終的な輸入量を推定するにあたっては，これら 3 人 の専門家の意見を同じ比重で考慮することとし, 関数 DUNIFORM でこれらの值をくくった（図17のセル C16)。

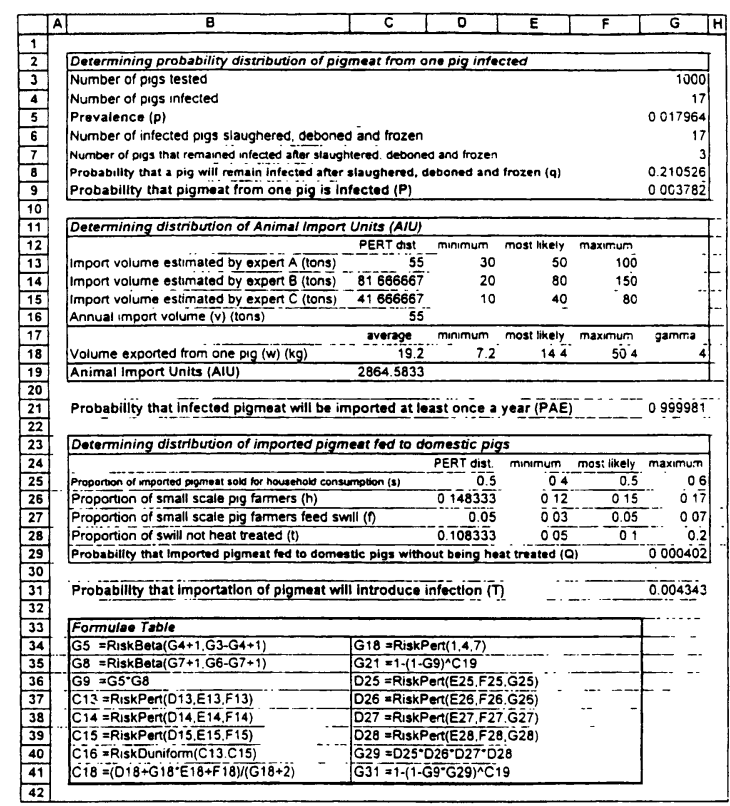

図18 具体例 2 の表計算モデル 2

一方, 豚 1 頭から輸出される豚肉の平均重量について は，A国における食肉流通統計等から，同国の豚枝肉の 平均重量は $72 \mathrm{~kg}$ であり, また, 1 頭分として最小値は ロイン系（歩留10\%）のみが輸出される場合, 最大值は フルセット（歩留70\%）で輸出される場合，最期待值は ロイン，かた，バラ（歩留20\%）が輸出される場合であ るとの食肉流通の専門家の意見を参考にして, 次のデー タを使うこととする。

\begin{tabular}{|c|c|c|c|}
\hline & 最 小 値 & 最期待値 & 最 大 値 \\
\hline 1 頭分の豚肉重量 w & $7.2 \mathrm{~kg}$ & $14.4 \mathrm{~kg}$ & $50.4 \mathrm{~kg}$ \\
\hline
\end{tabular}

AIU を求める算式の分母となる 1 頭分の平均豚肉重 量は, この表の推定値が三角分布をとるか, パート分布 をとるか等により異なってくる。すなわち， 三角分布の場合， $\mu=(\mathrm{a}+\mathrm{b}+\mathrm{c}) / 3(\mathrm{a}, \mathrm{b}$ 及び $\mathrm{c}$ は，そ れぞれ最小值，最期待値及び最大值。以下同じ。）

パート分布の場合, $\mu=(\mathrm{a}+4 \mathrm{~b}+\mathrm{c}) / 6$

さらに, 最期待值のウェイトを高めると, $\mu=(\mathrm{a}+7 \mathrm{~b}+$ c) $/ 9$ ここでは, 最小值, 最期待值及び最大值について確 固な解釈なないことから， $\mu=(\mathrm{a}+\nu * \mathrm{~b}+\mathrm{c}) /(\nu+2), \nu=\operatorname{Pert}(1,4,7)$ とし て, 1 頭分の平均豚肉重量を推定した（図17のセル $\mathrm{C} 18)$ 。

このようにして得られた年間輸入量及び 1 頭当たりの 平均重量の值を式(3)に代入し，AIU を求め（図17の七ル C19)，これを(1)で求めた $\mathrm{P}$ の分布とともに式(2)に代入 することにより，P A E が求められる（図17のセル G21)。シミュレーションの結果は, 表 4, 図18-1 及び 図18-2のとおりである。

（4） A 国から仮に骨なし冷凍豚肉の輸入を全面解禁し た場合，同輸入が原因で疾病 Zが $\mathrm{B}$ 国で年間少なくとも 1 件発生する確率

疾病 $Z$ の病原体に污染された骨なし冷凍豚肉が輸入さ れても，B国内で感受性動物に暴露されなければ，疾病 $Z$ の発生には至らない。仮に疾病 $Z$ の病原体が残存する 豚肉が $\mathrm{B}$ 国に輸入された場合，国内の感受性動物に暴露 するシナリオは数多く存在するが, 豚に残飯として給与 されることにより発生するとのシナリオが最も可能性が 高く, それ以外のシナリオによる暴露の可能性は残飯給 与による暴露の可能性に比べきわめて小さいことから無 視できるとする。A国から 1 頭分の污染豚肉が輸入され た場合，感染力を維持したまま豚へ給与される確率は， 図19のイベント・ツリーから次のとおりである。

$$
\mathrm{Q}=\mathrm{s} * \mathrm{~h} * \mathrm{f} * \mathrm{t} \quad \cdots \text { (4) }
$$

ここで $\mathrm{h}$ は，B 国における全家計戸数に対する小規模 養豚農家の戸数の割合, $\mathrm{f}$ は, 小規模農家のうち残飯を豚 に給与する養豚農家の割合であり, $\mathrm{t}$ は，残飯が未加熱の 豚肉を含む機会の割合である。

したがって, A国からの AIU 頭分の骨なし冷凍豚肉の 輸入された場合に，少なくとも年間 1 頭分が感染力を維 持したまま $\mathrm{B}$ 国の感受性動物に暴露される確率 $\mathrm{T}$ は, 次 により計算される。

$$
\mathrm{T}=1-(1-\mathrm{P} * \mathrm{Q}) \wedge \mathrm{AIU} \cdots(5)
$$

種々の統計資料, 専門家による意見から, これらの変数 の值を次のとおり推定し，これらはいずれもパート分布 をとるものとした。

$$
\text { このシナリオ・ツリー及びデータの一部については, }
$$




\begin{tabular}{|c|c|c|c|}
\hline & 最小值 & 最期持值 & 最大值 \\
\hline 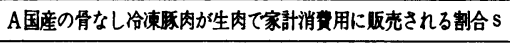 & $40 \%$ & $50 \%$ & $60 \%$ \\
\hline 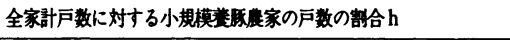 & $0.13 \%$ & $0.15 \%$ & $0.17 \%$ \\
\hline 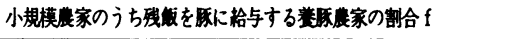 & $3 \%$ & $5 \%$ & $7 \%$ \\
\hline 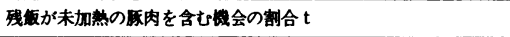 & $5 \%$ & $10 \%$ & $20 \%$ \\
\hline
\end{tabular}

豪州がカナダ産豚肉の輸入解禁に伴い豚伝染性胃腸炎が 侵入する危険度を求めた例 ${ }^{11}$ を参考にした。これらの値 を式(4)に代入することにより，Qの值を求め，Qの值を (1) で求めた P の值及び(3) で求めた AIU の值とともに 式(5に代入することにより，A国からの AIU 頭分の骨な し冷凍豚肉の輸入された場合に, 年間少なくとも 1 頭分 が感染力を維持したまま $\mathrm{B}$ 国の感受性動物に暴露される 確率Tの值が得られる(図17のセル G31)。シミュレーシ ョンの結果は, 表 4 , 図20-1 及び図20-2のとおりで ある。ドーズ・レスポンスに関するデータは存在しない
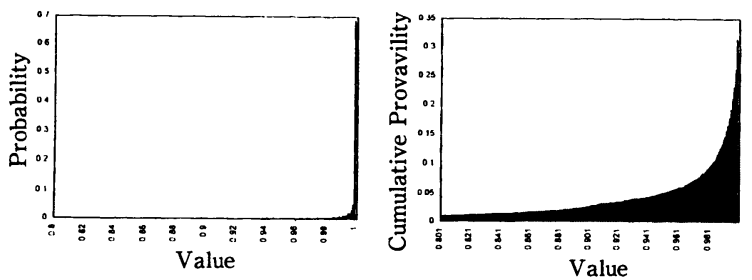

図19骨なし冷凍胘肉の输入を全面解禁した場合に污染豚肉が年間少なくとも 1 頭分输入される確率の分布
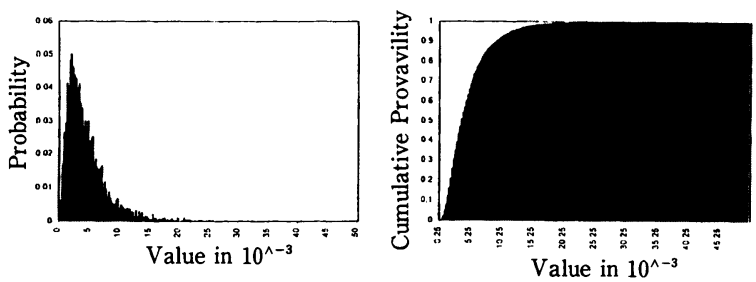

図20骨なし冷凍豚肉の輸入を全面解禁した場合に輸入国内で年間 1 回疶病の 発生が生じる確率の分布

ところ，疾病 Zの病原体を含む豚肉を食べた豚はすべて 感染すると仮定すると，Tの值はそのまま，A国からの 輸入が原因で疾病 $Z$ が年間少なくとも 1 件発生する確率 に相当する。

(5) 感度分析

@ Riskには, 出力変数を計算する際に使われた入力変 数のうちどの変数が出力変数に与える影響が大きいかを 調べる感度分析を行う機能がある。この機能を使って, どの入力変数がTの值に最も大きな影響を及ぼすかを調 べてみたところ, 図21の結果が得られた。Tに影響を与 える 8 つの力変数のうち, 感染豚から生産された骨抜 き冷凍豚肉に疾病 $Z$ の病原体が残存している確率 $\mathrm{q}$ の影

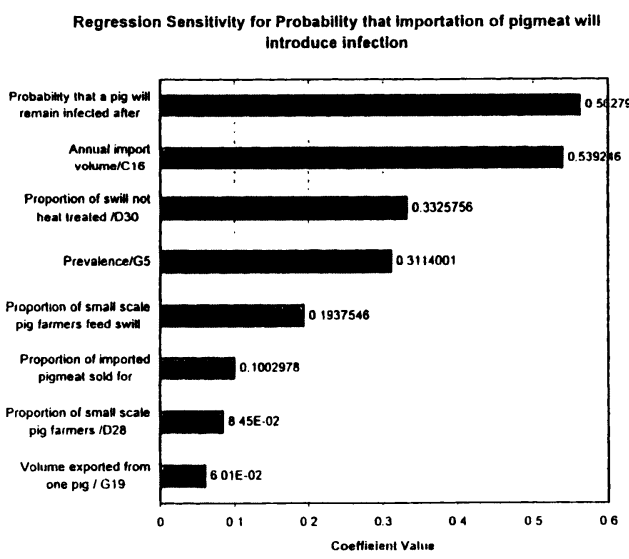

図21 具体例 2 の感度分析の結果
響力が最も 大きく, 輸 入量 $\mathrm{v}$, 残 飯が未加熱 で給与され る割合 $\mathrm{t}$, 有病率 $\mathrm{p}$ と 続く。各バ 一の先端に 記載された 数值は, 回 帰係数であ $\eta$, この值 が1である ことは, この入力変数の值が 1 標準偏差だけ変化すると 出力変数の值（この場合， $\mathrm{T} の$ 值）も 1 標準偏差だけ変 化することを意味する ${ }^{1)}$ 。入力変数が出力変数に与える 影響が大きいということは，これらの入力変数の值が不 確実性を反映し幅広い確率分布を有することを意味する と同時に，これらの入力変数の值を小さくすれば，Tの 值，すなわち，危険度も効果的に低減できることを示し ている。この例においては，たとえば，A国における豚 のと殺・処理過程における病原体の死滅処理の強化，B 国内における豚への残飯給与の禁止などにより，危険度 の低減を効果的に図ることができる。

（6）輸入危険度評価の結果の解釈

定量的危険度評価により求められた危険度の值が受け 入れられる水準か否かについて判断するための国際的な 基準はない。しかしながら，過去の例をみると，二ュー ジーランドがカナダ産の鮭の切り身の輸入に伴う危険度 評価を行った結果, 女っそう病の発生が100万トンの輸入 当たり 1 回未満にとどまることから，危険度は無視でき るほど小さいとした例 ${ }^{12)}$, 米国がアルゼンチンからの骨 なし牛肉の輸入に伴う危険度評価を行い，年間 2 万トン 輸入した場合に 45 万年に 1 回発生するとの結果を無視で きるほど小さいとした例 ${ }^{14)}$ がある。このように, 危険度分 析の結果得られた危険度の值をどう解釈するかについて は，現在までのところ，各国の家畜衛生事情，危険度に 対する態度の違いもあり，国際的な基準はないが，基準 作成の試みはなされている。Zepeda Sein ${ }^{13}$ は 1 年間に 100 万分の 1 以下の確率での発生を無視できる危険度 (negligible), 100万〜 10万分の 1 の確率の発生を低危険 度 (low), 10万〜千分の 1 の確率の発生を中危険度 (moderate), 千分の 1 以上の確率での発生を高危険度 (high) とし,これらの発生の危険度と問題となる疾病の 経済的インパクトの組合せにより最終的な判断の参考と 
なる基準を提案している(表 5 )。仮にこの基準を上記の 例に適用した場合，信頼度 $95 \%$ で疾病 Z が発生する危険

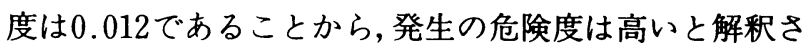
れ，疾病の経済的インパクトの度合によっては最終的な 危険度は中又は高危険度となる。したがって，B国の獣 医当局は, 危険度の低減を図り, 危険度を低減させた上 で輸入解禁を行うか, 危険度低減措置の実施が困難な場 合は，A国内における有病率がさらに低下するまでは輸 入禁止を継続せざるを得ないという判断を行うことがで きる。

表 5 危険度の分類

\begin{tabular}{|c|c|c|c|c|}
\hline \multirow[b]{2}{*}{ 発生の危険度 (注2) } & \multicolumn{4}{|c|}{ 疾病の柽済的インパクト (1) } \\
\hline & $\begin{array}{l}\text { 乘めて小さい } \\
\text { (Negligible) }\end{array}$ & $\begin{array}{l}\text { 小さい } \\
\text { (Low) }\end{array}$ & $\begin{array}{c}\text { 中程度 } \\
\text { (Moderate) }\end{array}$ & $\begin{array}{l}\text { 大きい } \\
\text { (High) }\end{array}$ \\
\hline 極めて低い(Negligible) & $\mathrm{N}$ & $\mathrm{L}$ & $\mathrm{L}$ & $M$ \\
\hline 小さい(Low) & $\mathrm{L}$ & $\mathrm{L}$ & M & M \\
\hline 中危侩度 (Moderate) & L & $\mathrm{L}$ & M & M \\
\hline 大きい(High) & M & M & $\mathrm{H}$ & $\mathrm{H}$ \\
\hline
\end{tabular}

注 1 : 疾病の程济的インバクトの大きさの各定義は次のとおり。

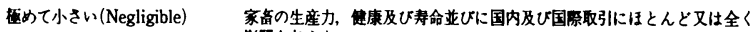

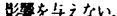

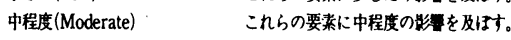

大きい(High) :これらの要菜に更

大な䩪を及任才。

拄 $2 \cdot$ 発生の危険度の大きさの各定義仕次のとおり。

传めて小さい(Negligible)

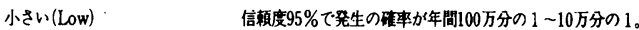

中程度(Moderate)：信頼度 $95 \%$ で発生の体が年間 10 万分の 1 千分の 1 。

大きい(High) ·信頛度 $95 \%$ で

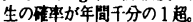

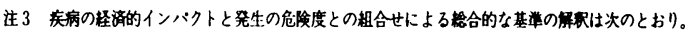

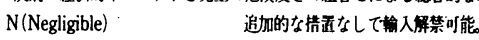

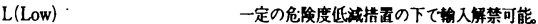

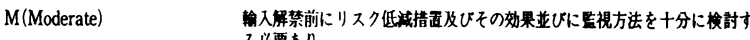

ろ必要おり。

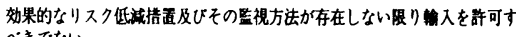
べきでない。

\section{6. 結 論}

基本的な確率のルール及び確率分布の知識を修得する ことにより, 危険度 (確率) の分布を計算するための危 険度評価モデルの構築が叮能となる。特に，モンテカル ロ・シミュレーションを用いることにより数学的に極め て複雑な計算を行わなくても確率分布等の推定が可能と なるほか，直感的にわかりやすいモデルの構築が可能と なる。獣医当局, 農家などの措置の決定者は, 定量的危 険度評価の結果得られた危険度の值を参考にすることに より，より客観的な決定を行うことができる。さらに， 感度分析を行うことにより，どのようなデータが不足し ているのか，どのようなリスク管理措置が効果的なのか が明らかになる。

\section{参考文献}

1) Anon: A Guide to Use @ RISK-Advanced Risk Analysis for Spreadsheets. Palisade. New York, 1997

2 ) Anon: Report of the meeting of the Ad hoc Group on Import Risk Analysis held in Paris, 1-2 October 1998, OIE. Paris, 1998

3 ) Anon: OIE Scientific and Technical Review Volume 16 (1) -Contamination of animal products: prevention and risks for animal health, OIE. Paris, 1997

4 ) Anon: OIE Scientific and Technical Review Volume 16 (2)-Contamination of animal products: prevention and risks for public health, OIE. Paris, 1997

5 ) Anon: OIE Scientific and Technical Review Volume 12 (4)-Risk Analysis-animal health and trade, OIE. Paris, 1994

6 ) Anon: OIE International Animal Health Code-mammals, birds and bees-Special Edition, OIE. Paris, 1997

7 ) Cameron,A.R, Baldock, F.C.: A new probability formula for surveys to substantiate freedom from disease, Preventive Veterinary Medicine 34, pp1-17, Elsevier,1998

8 ) Clemen, R.T., Making Hard Decisions-An Introduction to Decision Analysis-Second Edition, Duxbrry Press, Pacific Grove, 1997

9 ) Toma, B. et al.: Epidemiologie Appliquee a la Lutte Collective contre les

Maladies Animales Transmissibles Majeures. AEEMA, Maison-Alfort, 1996; 杉浦勝明訳：獣医応用疫学. 文永 堂, 東京, 1997

10) Vose, D.: Qunatitative Risk Analysis-A Guide to Monte Carlo Simulation Modelling. John Wiley \& Sons, Chechester, 1996

11) MacDiarmid, S.: The Importation into New Zealand of Meat and Meat Products-A Review of the Risks to Animal Health, Ministry of Agriculture and Fisheries, New Zealand, 1991

12) MacDiarmid, S.: The Risk of Introducing Exotic Diseases of Fish into NewZealand Through the Importation of Ocean-caught Pacific Salmon from Canada, Ministry of Agriculture and Fisheries Regulatory Authority, New Zealand, 1994

13) Zepeda Sein,C.: Regional Standard for the Formulation of Animal Health Risk Analyses, in the report of Seminar on Safegurding Animal Health in Tradein the Caribbean,held in Port of Spain, 9-11 December, 1997, OIE. Paris, 1998

14) Anon: Risk Assessment to Determine the Risk of Importation of Fresh, Chilled, Deboned Beef from Argentina conducted by the APHIS Review Team,2026 November, 1994, USDA, 1995 